\title{
The composition of reformed church orders: A theological, reformed and juridical perspective
}

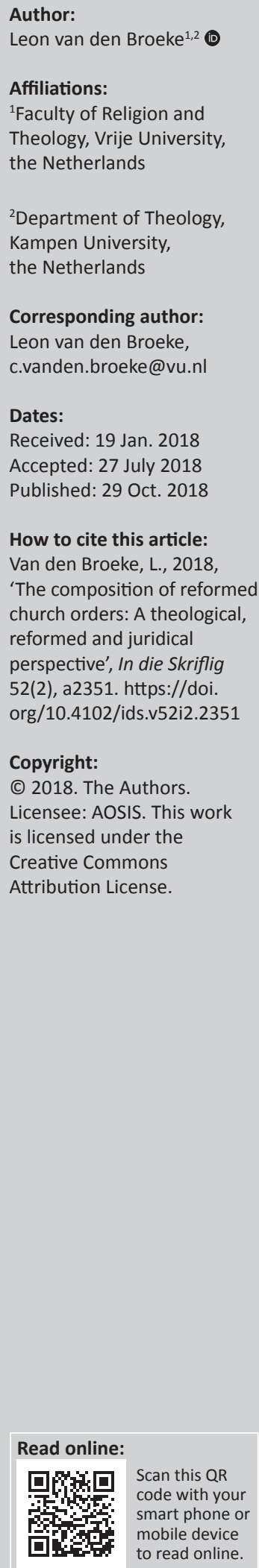

Many reformed church orders, which reflect the Dort Church Order of 1619, albeit revised, still apply its subdivision into these four chapters: firstly, offices (dienste); secondly, general assemblies (samekomste); thirdly, doctrine, sacraments and other ceremonies (leer, sakramente en seremonies); and fourthly, church discipline (kerklike tug). This article focuses on the composition of church orders. The research question is the following: How are reformed church orders composed and what it the ecclesiological or juridical rationale behind this composition? This article contains paragraphs on the composition and the ecclesiological legitimisation of the Dort Church Order of 1619 and its predecessors, the reformed churches in the East-Indies (Batavia), the Algemeen Reglement of 1816, the Reformed Church Order of 1951, the church order of the Protestant Church in the Netherlands of 2004, and the major shift from the perspective of canon law to reformed church polity. Reformed church orders contain both doctrinal and disciplinary regulations in relation to three notae ecclesiae of a reformed church. However, there is more at issue than the theological nature of the composition of the Dort Church Order and its successors, namely their relation to the Institutes of Justinian.

\section{Introduction}

The church order of the Reformed Churches in South Africa (RCSA) states in its brief introduction that the Synod of Reddersburg (1862) had adopted the Dort Church Order of 1619 for its church government. Successors of this synod have revised this church order according to its lawful or legal authority based on article 86 . However, it is the division which still reflects that of the Dort Church Order of 1619.

Article 1 of the church order of the RCSA states:

Om goeie orde in die kerk van Christus te onderhou, is daarin nodig: die dienste, samekomste, toesig oor die leer, sakramente en seremonies en die kerklike tug, waaroor hierna agtereenvolgens gehandel word.

This is just one of the many reformed church orders around the globe. In one way or another, many of them still apply the subdivision of the Dort Church Order of 1619 into firstly, offices (dienste); secondly, general assemblies (samekomste); thirdly, doctrine, sacraments and other ceremonies (leer, sakramente en seremonies); and fourthly, church discipline (kerklike tug).

This article focuses on the composition of church orders for the reason that in 2019 it will be 400 years since the famous Dort Church Order of 1619 became valid and because not much research has been undertaken in this field as far as I can see. I was encouraged to undertake this research on the composition of, or the division into chapters of reformed church orders, and more specifically, the Dort Church Order of 1619. Much has already been written about the ecclesiological content of such books and about their juridical framework, but hardly anything about the composition and division into chapters. ${ }^{1}$ The Dutch professor in Church History and Church Polity at the Theologische Hogeschool, Kampen (Oudestraat), Harm Bouwman (1863-1933), paid some attention to the composition of laws in his historical overview, in Gereformeerd Kerkrecht. He refers to the composition of laws and their division into persons, business and acts (Bouwman 1928-1934, 2:50-52; Constitution Society 1995, 2:12). The Utrecht professor of church polity, Gisbertus Voetius (1589-1676) took over this composition (Voetius, 1663-1676). In general, Bouwman was quite negative about the composition of laws of the Emperor Justinian. He was of

Balke and Oostenbrink-Evers (1993. 1995). Bos (1950); Brink and De Ridder (1980). Church Order of the Free Reformed Churches of Australia (2015); Coertzen (1992 ; 1998; 2004); De Wet (1921); Deddens (1988); Du Plessis (1924); Du Plooy (2012); Duursema (2017a; Australia (2015); Coertzen (1992; 1998; 2004); De Wet (1921); Deddens (1988); Du Plessis (1924); Du Plooy (2012); Duursema (2017a; and Spoelstra (1966); Nauta (1971); Nauta and Van Dooren (1978); Oostenbrink-Evers (2000); Opitz (2006); Pont (1981); Schutte (2002); Smit (1986); Strauss (2013); Van't Spijker (1992); Van 't Spijker, De Bruin, Florijn, Moerkerken \& Natzijl (1994); Van Boetzelaer Van Dubbeldam (1906); Van Dellen \& Monsma (1941; 1790); Van der Linde (1965; 1983); Van Dooren (1981); Van Rongen and Deddens (1986); Van Wyk (2017); Wagenaar (1993). 
the opinion that, by this division of laws, church polity was affected too much by civil law. Bouwman divided his twovolume Gereformeerd kerkrecht into a historic and a thetic part. This last part was divided into the church and the office; the church and its governance; the church and the administration of sacraments and ceremonies; the church and admonition and discipline; and the church and its relationship with the civil authorities.

The Dutch expert in church polity, Johannes Jansen, (1873-1956) wrote in 1952 that to maintain good order in the church of Christ four elements are necessary: offices, assemblies, supervision of doctrine, sacraments and ceremonies, and Christian discipline. Jansen refers to article 1 of the Dort Church Order of 1619. Jan Hovius (1900-1979), professor at the Theologische Hogeschool Apeldoorn, wrote in 1962 about the first article of the Dort Church Order of 1619 that the division into chapters forms a pattern of church order which matches the pattern of biblical church polity, as expressed in the confession (Hovius 1962). In 1971, another Dutch expert in reformed church polity, Doede Nauta (18981994), wrote about the Acts of the Synod of Dordrecht of 1578, which were divided into six sections. He expressed the view that its predecessors (Emden 1571 and Dordrecht 1574) were not concerned with systematising their content, but were intended to answer particular questions. Detmer Deddens (1923-2009), professor in Church History and Church Polity at the Theologische Hogeschool Kampen, wrote about the division of the reformed church orders after the Synod of Middelburg of 1581, but did not reveal the reason for the specific division into the above-mentioned four chapters (Deddens 1988:113).

An expert in reformed church polity who did elaborate rather more on the division into chapters, was the South-African theologian Smit (1946-2011). He (Smit 1984) wrote:

Die kerkorde het nooit die pretensie gehad van 'n volledige kerklike wetboek wat vir alle moontlike voorkomende situasies en probleme antwoorde moet gee nie (Pont 1981:147). Slegs die rigtinggewende beginsels is daarin neergelê. Die bestek van die kerkorde, soos geformuleer op Dordrecht (1618-1619), is omlyn deur vier hoofafdelings, naamlik:

(i). Oor die dienste of ampte: artikel 2-28.

(ii). Oor die kerklike vergaderings: artikel 29-52.

(iii). Oord die leer, sakramente en seremonies, artikel 53-70.

- Die doop: artikel 55-60.

- Die nagmaal: artikel 61-63.

- Die orde van die preekdienste; artikel 64-70.

(iv). Oor die sensuur en kerklike vermanings: artikel 71-86. (p. 119)

In addition Smit (1984:119) states: 'Hierdie hooflyne loop as 'n formulering van die toepaslike skrifbeginsels dwarsdeur die historiese ontplooiing van die kerkorde, hoewel dit nie aanvanklik op die wyse gesistematiseer is nie.' He refers to Pont (1981:146-147): 'In plaas dus van 'n volledig uitgewerkte kerklike wetboek wat vir alle moontlike voorkomende situasies en probleme antwoorde gee, word hier slegs die rigtinggewende beginsels neergelê.' Other Dutch, North-American and South-African books pay little attention to the topic of the composition or division of the Dort Church Order of 1619, other than just refering to the importance of the second part of its article 1 .

My research question is as follows: How are reformed church orders composed and what is the ecclesiological or juridical ratio behind this composition? In paragraph 2, I research the composition and the ecclesiological legitimisation of the Dort Church Order of 1619 and its predecessors. Paragraph 3 shifts the spotlight to reformed churches in the East-Indies (Batavia). Paragraph 4 discusses how an ecclesiological shift concerning Dutch Reformed church orders took place in 1816 when King Willem I (1772-1843) imposed his centralistic church order. In paragraph 5, I address the Reformed Church Order of 1951 and the church order of the Protestant Church in the Netherlands of 2004. In order to understand the major shift from the perspective of canon law to reformed church polity, paragraph 6 will deal with the composition of canon law in the Roman Catholic church in the 16th century. Paragraph 7 contains the conclusions and the answer to the central question on the composition of reformed church orders.

\section{The Dort Church Order of 1619 and its predecessors}

As a result of the 16th-century Protestant reformation church polity, the reformers rejected not only Roman Catholic soteriology, sacramentology and ecclesiology, but also the system of canonical law of the Roman Catholic church. It is one thing to break away from a system. It is another thing to organise a replacement church order and to implement it. This does not only apply for the office of bishop and the whole hierarchical system of canon law, but also to the composition of a new (reformed) book of 'canon law'. In this paragraph, the division into chapters in the predecessors of the Dort Church Order of 1619 will be researched.

\section{Pre-Dort developments: 1571-1619}

The decisions of the Synod of Emden of 1571, the Synod of Dordrecht 1574 and the Synod of Dordrecht 1578 cannot be called 'church orders' - they simply contained 'acts'. The Synod of Middelburg of 1581 and the Synod of 's Gravenhage of $1586 \mathrm{did}$ set out church orders and were predecessors of the Dort Church Order of 1619. As from the 1581 Acts of the Synod of Middelburg, the church orders had the same composition as that made explicit in the first article of the Synod of Middleburg (Middelburg 1581, 's Gravenhage 1586 and Dordrecht 1619):

- Vande Diensten (Of offices);

- Vande 't Samenkomsten (Of General Assemblies);

- Vande Leere Sacramenten en andere Ceremonien (Of Doctrine, sacraments and other ceremonies);

- Vande Censuere, ende Kerckelijcke Vermaninghe (Of Admonition and Discipline).

The aim of the introduction in the first article was to maintain good order in the church of Christ with reference 
to 1 Corinthians 14:40. The first two books of acts (Emden 1571 and Dordrecht 1574) did not have this introduction, and the book of acts of the Synod of Dordrecht of 1578 had a more extended division.

Again, from 1581, it appears that the early reformed church orders contained in general the same four main chapters, unlike Emden 1571, Dordrecht 1574 and Dordrecht 1578 with its extended division. This is not surprising: only as from the Synod of Middelburg of 1581 are the acts transformed into a 'church order' and are named as such. The Acts of Dordrecht 1578 also contain special chapters on schools (between the chapter on general assemblies and those on doctrine, sacraments and other ceremonies) and on marital law (between the chapters on the doctrine, sacraments and other ceremonies, and on church discipline). As from the following synod, these chapters disappeared. Apparently, in 1578 schools were considered to be particularly important. The chapter on marital law is fascinating, because it demonstrates less discontinuity with Roman Catholic canon law. Marital law was in the past and is still today an important aspect of the canonical law system. This does not apply with the reformed system. That does not mean that marriage was not an important issue for reformed ecclesiology and liturgy. However, it was not considered essential in ecclesiastical life.

In the Acts of the Synod of Dordrecht of 1578, the first chapter on the offices, unike its successors, was not called 'Vande Diensten', but it did specify the offices of ministers of the Word, elders and deacons (Van den dienaren des Woordts, ouderlinghen ende diaconen).

This overview raises the question of whether these acts and church orders reflect the 16th-century Genevan or French church orders.

\section{The Genevan Articles 1537}

On 16 January 1537, John Calvin (1509-1564) and Guillaume Farel (1489-1565) presented their draft church order - the socalled Articles concernant l'organisation de l'église et du culte a Genève, to the city council of Geneva. These articles formed the predecessor of the Ordonnances Ecclesiastiques of 1541. They start with this statement: 'Il est certain que une esglise ne peut estre dicte bien ordonnee et reiglee synon en la quelle la saincte Cene de nostre Seigneur est souuentefoys celebree et frequentee' (CO 1871:5). This demonstrates the fact that the church order is a Eucharistic order. According to Calvin and Farel, the Lord's Supper needed to be celebrated often and frequently. Although the Lord's Supper is not the only item in the articles, it is an essential part, a fundamental expression of a liturgical ecclesiology. Together with the other three chapters, the composition of the articles is as follows: the Lord's Supper, singing of psalms, instruction of youth and marital law. The nature of the articles of 1537 was liturgical, about the Lord's Supper, singing of psalms (not hymns) and marriage law. A fourth part concerned the instruction of the youth. These articles were not implemented, because Farel and Calvin disagreed with the civil magistrates. In 1538, they were forced to leave Geneva. It appears that the composition of the articles of 1537 was quite different in comparison with the Dort Church Order of 1619.

\section{The Genevan Ordonnances Ecclésiastiques of 1541 and 1561}

When Calvin returned to Geneva in September 1541, he proceeded with the composition of a church order. This new church order, contained in the Ordonnances Ecclesiastiques of 1541 and 1561, is quite different from the articles of 1537. The two orders are similar in compostion, although they do have their differences for which there is no space to set out here.

It is fascinating that the ordinances include lists of first- and second-rate sins. This is quite exceptional, at least from the perspective of Dutch Reformed church orders. Including lists of sins in the Ordonnances, demonstrate the fact that the Genevan church order was also an expression of reformed ethics and harmartology (the doctrine of sins). The lists of sins formed a part of the church discipline.

The Ordonnances also show a great deal of attention to liturgical law: about sacraments, baptism, the Lord's Supper, ecclesiastical songs, marriage, funeral and pastoral work which specifically includes visiting prisoners and congregants who were ill. Therefore, the Ordonnances also have a pastoral aspect.

They also include chapters on pastors, doctors, elders and deacons, the consistory, and discipline. There is no chapter on general assemblies as, for example classis, assemblies or synods. There were no such supralocal ecclesiastical bodies in Geneva. In general, the Ordonnances Ecclésiastiques of 1541 and its revision of 1561 were not divided into the same four chapters as the Dort Church Order of 1619, although they did contain sections on offices, the consistory (but not the classis assembly and synods), doctrine, liturgy and sacraments, and on admonition and discipline.

\section{The French Discipline Ecclésiastique of 1559}

The Synod of Paris, which gathered on 25 May 1559, accepted the Discipline Ecclésiastique of 1559 for the French Reformed Church. It was not comparable to the Genevan church, because the French church was a national church and not a city-state church. The French Church Order was composed of the following chapters in Box 1 :

This overview shows that the French Church Order had far more components than the Genevan Articles of 1537. The French Church Order started with the offices of minister, deacon and elder. The next chapter is about consistories. Between this and further chapters on general assemblies (provincial and general or national synods), there is a chapter on church discipline. Other chapters concern liturgical law and ethical law: baptism, Holy Communion, marriages and divorces. The last part is about Aduertissemens pour les particuliers [the position of congregants]. 
BOX 1: The chapters of the French Discipline Ecclésiastique of 1559.

\begin{tabular}{|c|c|}
\hline Des Ministres & Ministers \\
\hline Des Diacres et anciens & Deacons and Elders \\
\hline Du Consistoire & The Consistory \\
\hline $\begin{array}{l}\text { Des Delinquans, et de la censure qui doit } \\
\text { estre appliquée ... }\end{array}$ & $\begin{array}{l}\text { Delinquents and the discipline that } \\
\text { needs to be applied ... }\end{array}$ \\
\hline Des Synodes Provinciaux & Provincial Synods \\
\hline Des Synodes nationaux ou generaux & National or General Synods \\
\hline Du Baptesme & Baptism \\
\hline De la Cene & The Lord's Supper \\
\hline Des Mariages & Marriages \\
\hline Des Divorces & Divorces \\
\hline Aduertissemens pour les particuliers & Considerations about the congregants \\
\hline
\end{tabular}

At first sight, this seems to differ from the Dort Church Order of 1619. Although the first chapter concerns offices in general, the next chapter is not about general assemblies, but the consistory. It is followed by admonition and discipline before particular and general synods. There are individual chapters dealing with liturgical law: regulations on baptism, the Lord's Supper and marriage. In addition, a special chapter on divorce is added. Although the Dort Church Order of 1619 does not exactly reflect the French Church Order, to a certain extent it has the same corpus. In general, the Discipline Ecclésiastique of 1559 resembles the composition of the Dort Church Order of 1619: offices, general assemblies, liturgical law and - in between - admonition and discipline.

\section{Analysis}

Willem van 't Spijker, emeritus-professor of Church History and Church Polity at the Theological University of Apeldoorn in the Netherlands, states that reformed church orders are based upon doctrina and disciplina (Van 't Spijker 1992:1995-1011). In reformed church polity, these are closely connected. A reformed church order should express God's salvation and protect the pure preaching of the gospel and the pure administration of the sacraments, and should apply ecclesiastical discipline and admonition - the three true marks of the church according to the Belgic Confession, article 29. The South-African emeritus-professor Andries le Roux du Plooy agrees. He (Du Plooy 2012) expresses his view in an article in In die Skriflig/In Luce Verbi:

Die ontstaan en ontwikkeling van die teks van die kerkorde het in die 16de eeu tot vroeg in die 17de eeu plaasgevind, en het met die nasionale sinode van Dordrecht in Nederland in 1618 en 1619 sy beslag gekry. Hierdie ontwikkeling het parallel verloop met die leerstellige ontwikkeling van die gereformeerde belydenisskrifte. Die doctrina en die disciplina van die kerk het hand aan hand ontwikkel en is onlosmaaklik verbind aan mekaar. (p. 3)

Du Plooy (2012) elaborates on the authority of the church order that is based on the Scripture and the confession:

Die gesag van die kerkorde lê nie in homself nie, maar in sy verbondenheid aan die Skrif en belydenis. Die aard van die gesag is bedienend, en rus eintlik op twee ongelyke bene: eerstens op die Woord van God, en tweedens op die feit dat kerke in kerkverband onderling met mekaar ooreengekom het (mutuo consensu) om hulle te bind aan die artikels van die kerkorde ooreenkomstig artikels 31 en 86 . Na binne het die kerkorde sodoende bindende krag en word dit as die geldende reg beskou en onderhou. Dit is bekend as die ius constitutum. (p. 3)

One could argue that the composition of reformed church orders demonstrate these three marks. Indeed, reformed church orders are about doctrine and discipline as their content shows. This is according to John Calvin (1509-1564) who "nie 'n "konstitutsie" ontwerp het en so 'n "kerk gestig" het nie. Anders gesê: Die kerk is vir Calvyn in sy wese organisme en nie instituut nie, al het die organisme 'n institutionele patroon', and: 'Die kerk is 'n pneumatiese organisme' (Spoelstra 1981:6) As a result, the church order must also be pneumatic. Bohatec (1968) stated on the basis of Calvin:

Es ist das Recht Christi, das (...) als Wortrecht und Geistesrecht bezeichnet werden kann (...) Weil es in Christus und seinem Wort verwurzelt, so sind von ihm geregelten alle kirchlichen Ordnungen pneumatisch. Darum ist die Kirchenverfassung pneumatisch. Das Ordnungsrecht der Kirche ist daher kein weltliches Recht, keine juristische zwingende Gemeinschaftsordnungen, sondern ein pneumatischen Ordnungsrecht. (p. 570)

\section{Smit (1987) agrees:}

Maar God se reg en orde is nie ' $n$ juridies uitgewerkte, reeds gepositiveerde regsorde vir sy kerk nie. Uit die neergelegde beginsels in die Woord van God vir die ontstaan, die bestaan en die voortbestaan van die kerk, moet deur die kerkreg God se reg vir sy kerk nagevors, verklaar en toepaslik gemaak word. (p. 18)

It means that a reformed church order is 'nie maar net ' $n$ neutrale orde-bundel nie. Belangrike beginselstandpunte lê so 'n dokument ten grondslag. Daarom is ' $n$ kerkorde self ook voorwerp van besinning deur kerkreg' (Coertzen 1992:718). Coertzen (1992) also states:

'n 'Goeie' kerkorde wat ook inderdaad as God se reg vir sy kerk bedien word, is weliswaar nie die waarborg vir geestelike volwassenheid nie, maar dit skep ten minste die ruimte waarbinne God se geregtigheid en vrede tot openbaring kan kom. (p. 718)

Not only South-African theologians share this position, but also Nauta (1971) who quoted Jean Crespin (ca.:1520-1574):

Deze kerkorde is niets anders dan een geestelijke verordening (reglement Spirituel) welke zich uitdrukkelijk grondt op Gods gebod. Zij heeft tot doel dat het Woord ongerept bewaard worde, niet bedorven noch vervalst, dat de sacramenten door de bozen niet ontwijdt worden; dat degenen die tot opdragt hebben de gemeente te onderwijzen en over haar opzicht te voeren, op wettige wijze geroepen worden tot hun ambten en deze naar behoren vervullen, dat degenen die zich scharen onder de verkondiging van het Evangelie, haar tot werking brengen door een goede en heilige evenswandel, steeds volhardend in gehoorzaamheid jegens God en de Overheid en in alle verplichtingen en liefde jegens hun naaste. Dit alles moet daartoe leiden dat God verheerlijkt, het rijk van Jezus Christus, Zijn Zoon bevorderd en zijn kerk gebouwd en van alle ergernissen gezuiverd word. (pp. 9-10)

Also Koffeman (2014) can be included:

(...) in my view church polity is related to theology, either implicitly or explicitly (...) Every church order is based on 
theological choices made, e.g. regarding ministry and the role of laity, regarding human powers and the Holy Spirit, regarding local and supra-local manifestations of the church, or regarding the relation of the church to civil government and society. (p. 13)

He (Koffeman 2014) elaborates on this by refering to Calvin:

(...) the Reformed tradition focuses entirely on God's action in predestination, and from that perspective it develops an ecclesiology of sanctification, in which the church is meant to help the elected Christians live up to the moral standars of divine election. (p. 33)

I agree that the nature and the content of a reformed church order is theological, scriptural and confessional. This content is put in a theological and juridical format. From the church polity view, law is not or should not be a bad, negative word. Calvin, himself, was a lawyer by education. In his Institutes he also expressed his views on law and order, for example with regard to 1 Corinthians 14:40:

(...) wanneer we willen, dat voor de welstand der kerk goed gezorgd wordt, moet er met zeer veel ijver gezorgd worden voor hetgeen Paulus beveelt, dat alle dingen eerlijk en met orde geschieden (...) Maar (...) is er ook geen regeringsinrichting sterk genoeg, wanneer ze niet door vaste wetten is geregeld, en kan ook geen gebruik in stand blijven zonder een bepaalde vastgestelde vorm. (Sizoo 1956, III:228-229)

The Spirit also makes use of structures, rules and law for the sake of the moral situation of humanity and their sanctification. The instrument of the Spirit is not less spiritual than the theological content of a church order - at least, they should not be less spiritual. Reformed church orders are indeed based upon doctrina and disciplina.

Still, we have not came across much about the composition of the reformed church order. However, from the perspective of the three reformed notions of the church: the preaching of the Word, the administration of the sacraments and the application of church discipline, there is more to say. The first two notions can be considered as essential elements of the offices (Vande Diensten) and indirectly also of general assemblies (Vande Samenkomsten). The classis assembly, and the particular and the general synods support the consistories in order that the Word can be preached and the sacraments administered in the local churches. The third chapter of the Dort Church Order (Vande Leere, Sacramenten en andere ceremonien) expressly addresses the first two notions. The third notion is connected to the fourth chapter of the Dort Church Order of 1619: of the admonition and church discipline (Vande Censuere en andere kercklicke vermaninghen). Lately, Strauss (2017) did refer to the composition of the reformed church order:

Steeds op die gereformeerde lyn betoog Jansen (1952:10, 11) dat 'n kerkorde vyf elemente (rubrieke) moet bevat vir die goeie orde van die kerk: die dienste of ampte, kerkvergaderings, seremonies en ander dienste of bedienings waaronder die sakramente en toesig oor die leer, die kerklike tug en die 'stoffelijke' sake van die kerk. Deur hulle herhaalde gebruik word sekere reëlings mettertyd gewoontes en in ' $n$ 'welomschreven ordening' opgeneem. Met die weglating van die stoflike sake sluit Spoelstra (1989:25) hierby aan. (p. 3)

Strauss not only refers to Spoelstra, but also to Janssen. As we saw above, Jansen (1952), just like Spoelstra and Strauss, did mention the composition of the reformed church order as one of the few. However, they do not elobarate on this, because they had another focus in their writings.

Looking back at the composition of the reformed acts and church orders in the Netherlands the overview demonstrates that they are not exact copies of the composition of the Genevan and French reformed church orders. They were composed in other ways, with fewer chapters.

\section{The Church Order of Batavia (1643)}

As an example of the contextual needs to adjust the Dort Church Order of 1619, from the perspective of the composition of the church order, this section focuses on the oversight of the churches in the East Indian Archipelego. The result was the church order for the church in Batavia in 1643 (Kerkorde voor de Bataviasche gemeente afgekondigd 07 december $1643 ; 1886)$, a revision of the Dort Church Order of 1619 to a certain extent following the pattern of that church order, although not exactly, as will appear from the overview in box 2 (Kerkorde 1986):

The appendix starts with article 72 . This states that Jesus Christ has provided the church with the specified offices, order, supervision of doctrine, sacraments and church discipline for the benefit of the church. However, life in this world is imperfect. The pastors, elders and deacons cannot deal with everything in their situation or be present in all cases at all times. In order that congregants should not suffer from this, the situation requires others to be authorised by the consistory with the approval of the civil authorities. More specifically, comforters of the sick and schoolmasters were appointed for the spiritual benefit of the congregation and the congregants. Article 72 introduces the division of the appendix chapters see box 3 .

The Batavian Church Order of 1643 reflects the division of the Dort Church Order of 1619. However, there are two separate chapters when it comes to the offices. The first is about offices in general. The second is concerned with elders and deacons. Because of its different cultural, societal, political and ecclesiastical context, the corpus of the Dort Church Order of 1619 was not entirely helpful to the East Indian churches. It required adjustment, mainly in respect of comforters of the sick and schoolmasters.

BOX 2: The chapters of the Dort Church Order (1619).

\begin{tabular}{|ll|}
\hline Of Offices & Van De Diensten \\
Of Elders and Deacons & Van De Ouderlingen Ende Diaconen \\
Of General Assemblies & Van De Tsaemencompsten \\
Of the Doctrine of the Sacraments and other & Van De Leere Der Sacramenten Ende \\
Ceremonies & Andere Ceremoniën \\
Of Adminition And Ecclesiastical & Van De Censuere Ende \\
Discipline & Kerckelycke Vermaninge \\
Appendix & Appendix \\
\hline
\end{tabular}


BOX 3: The chapters of the Church Order of Batavia (1643).

$\begin{array}{ll}\begin{array}{l}\text { Of Comforters of the Sick } \\ \text { Of The Comforter of The Sick In The } \\ \text { House of General 'Ontfangh' }\end{array} & \begin{array}{l}\text { Van De Cranckenbesoeckers } \\ \text { Van Den Cranckbesoecker In Het } \\ \text { Huys Van Den Generalen Ontfangh }\end{array} \\ \begin{array}{l}\text { Of the Comforter of the Sick in the } \\ \text { Hospital }\end{array} & \begin{array}{l}\text { Van Den Cranckbesoecker In't } \\ \text { Sieckenhuys }\end{array} \\ \begin{array}{l}\text { Of Schoolmasters } \\ \text { Of The Schoolmasters In The Orphen's } \\ \text { House }\end{array} & \begin{array}{l}\text { Van De Schoolmeesters } \\ \text { Weeshuys }\end{array} \\ \begin{array}{l}\text { Of Indigenous Schoolmasters } \\ \text { In the Bandanees Quarter } \\ \text { In The Mallabaers Quarter } \\ \text { In The Suburbs }\end{array} & \begin{array}{l}\text { In't Bandanees Quartier } \\ \text { In't Mallabaers Quartier }\end{array} \\ \begin{array}{l}\text { Instruments To Promote the Conversion } \\ \text { of the Heathens }\end{array} & \begin{array}{l}\text { Inde Voorstadt. } \\ \text { Middelen Om De Bekeeringe Der }\end{array}\end{array}$

\section{The Dutch General Regulations of $\mathbf{1 8 1 6}$}

In 1816 something new happened in the new kingdom of the Netherlands. King Willem I imposed a new church order in the Netherlands Reformed Church - the General Regulations of 1816. This was a breakaway from the ecclesiology and system of church polity of the Dort Church Order of 1619. The validity and the nature of this 1816 church order was heavily debated until it was replaced in 1951. The division of the General Regulations of 1816 makes clear that the ecclesiology of the new national church was centralised. It also reflects the administrative nature of the church that was far from spiritual. Also, it was far from being a reformed church order with any ecclesiological, let alone a reformed foundation.

After a first chapter on general regulations, the 1816 church order starts with 'of the Synod'. To emphasise the fact that this was the most important ecclesiastical body in the church, the first letter of the word 'Synode' was capatalised. This was not the case with the provincial, classical and local bodies (see box 4).

The centralised structure of the Netherlands Reformed Church was not only a new ecclesiology and contrary to the ecclesiology of Dort, but it correlated with the new political system. The Netherlands was no longer a confederation of seven independent provinces, but, since 1813, a kingdom. King Willem I, as summus episcopus, wanted ecclesiastical peace in his kingdom and not theological divisions. It was a new situation for the reformed church: one church order for one church. It was no longer the situation that every province had its own church order or adhered to the Dort Church Order of 1619 or its predecessors, but there was a (centralised) kingdom and a centralised Netherlands Reformed Church.

The new division also demonstrates that the Netherlands Reformed Church was an administrative church. The emphasis was not on office-bearers, church members or liturgy, but on the boards which were in charge as administrative bodies in order to rule in what today we would call a top-down church.
BOX 4: The chapters of the Dutch General Regulations of 1816

\begin{tabular}{|ll|}
\hline $\begin{array}{l}\text { First Chapter } \\
\text { (Eerste Afdeeling) }\end{array}$ & General regulations (Algemeene bepalingen) \\
$\begin{array}{l}\text { Second Chapter } \\
\text { (Tweede Afdeeling) }\end{array}$ & Of the Synod (Van het Synode) \\
$\begin{array}{l}\text { Third Chapter } \\
\text { (Derde Afdeeling) }\end{array}$ & $\begin{array}{l}\text { Of Provincial church Administration (Van het provinciaal } \\
\text { kerkbestuur) }\end{array}$ \\
$\begin{array}{l}\text { Fourth Chapter } \\
\text { (Vierde Afdeeling) }\end{array}$ & $\begin{array}{l}\text { Of Classis church Administration (Van het classikaal } \\
\text { bestuur) }\end{array}$ \\
$\begin{array}{l}\text { Fifth Chapter } \\
\text { (Vijfde Afdeeling) }\end{array}$ & $\begin{array}{l}\text { Of the Walloon, Presbyterian English, and Scottish } \\
\text { churches (Van de Waalsche, de Presbyteriaansche } \\
\text { Engelsche, en Schotsche Kerken) }\end{array}$ \\
$\begin{array}{l}\text { Sixth Chapter } \\
\text { (Zesde Afdeeling) }\end{array}$ & $\begin{array}{l}\text { Of the Circuits and similar gatherings (Van de ringen en } \\
\text { derzelver bijeenkomsten) }\end{array}$ \\
$\begin{array}{l}\text { Seventh Chapter } \\
\text { (Zevende Afdeeling) }\end{array}$ & $\begin{array}{l}\text { Of church administration in the congregations } \\
\text { (Over het kerkelijk bestuur in de gemeenten) }\end{array}$ \\
&
\end{tabular}

\section{The church orders of the Netherlands Reformed Church (1951) and of the Protestant Church in the Netherlands (2004)}

After 135 years, two major schisms (Afscheiding of 1834 and Doleantie of 1886), many ecclesiastical divisions and the Second World War, it became possible to implement a new realistic and more theological church order in the form of the Netherlands Reformed Church Order of 1951 (the Hervormde Kerkorde of 1951). The Dort Church Order of 1619 was considered unfit in the societal context of the 20th century, because it was focused on internal ecclesiastical affairs and the new context needed a new type of church order. This not only meant new content, but also a new composition for the church order. This was the view in 1945 of Wagenaar (1993), the composor of the draft church order, called 'Bouwplan Wagenaar':

De Dordtse Kerkorde was (...) daartoe niet geschikt, afgestemd als zij is op een geheel andere situatie dan waarvoor onze kerk thans staat. Zij regelde vooral de interne kerkelijke zaken en maar weinig de dienst der kerk aan en haar plaats in de wereld, haar hoofdmoment immers vindende in deze twee dingen: de strijd met de remonstranten over de leer en de strijd met de overheid over de staatsinvloed op kerkelijk erf. (p. XXXIX)

This says that the Dort Church Order of 1619 only made arrangements for internal ecclesiastical affairs, but did not focus on the service and place of the church in the world. Moreover, it states that the Dort Church Order of 1619 was constructed in a completely different societal context from the new 20th-century church order.

That is clear when we look at the composition of the church order of 1951. It was composed in a unique way. In general, it consisted of two parts: the constitution or the so-called Roman articles, and the ordinances. The nature of this constitution was theological. The ordinances were the administrative elaboration of the theological constitution. This division was comparable to the political situation: a constitution and organic laws. The latter are easier to revise than the constitution. The same goes for the new church order. Noteworthy was the fact that the article on Apostolate was placed before the article on confession. This does not 
necessarily mean that this church order was better than the Dort Church Order of 1619. The criticism, relief and joy over the Hervormde Kerkorde of 1951 in the Netherlands Reformed Church has to be understood against a backdrop of negative opinions about the collegialistic nature of the General Regulations of 1816 .

The new Netherlands Reformed Church Order of 1951 had 20 ordinances. It did not start with a chapter on offices, but on general assemblies. Chapter 4 on the apostalate of the church was remarkable. It reflects Wagenaar's statement that the Church Order of Dort 1619 was not focused on the service and the place of the church for the benefit of the world. The ordinances of the Netherlands Reformed Church Order of 1951 intended this outward perspective as is clear from its composition, specifically chapters 4 (Apostolate), 5 (Youth and School) and 12 (Marriage and family) see box 5.

In 1957, the separate Reformed Churches in the Netherlands adopted a revised version of the Dort Church Order of 1619: de Kerkorde van de Gereformeerde Kerken in Nederland. This was divided in the same way as the 17th-century church order so quite different than the above-mentioned church order of the Netherlands Reformed Church of 1951. However, in 2004 there was a merger between the Netherlands Reformed Church, the Reformed Churches in the Netherlands, and the Evangelical-Lutheran church in the kingdom of the Netherlands to form the Protestant Church in the Netherlands. This united church adopted the model of Netherlands Reformed Church Order of 1951. Although the number of the ordinances is more limited, the new order looks like its predecessor of 1951. An overview of the ordinances of the church order of the Protestant Church in the Netherlands 2004 is given in box 6 .

Notably, this church order neither start with general assemblies, nor with offices, but with the confession professed

BOX 5: The chapters of the church order of the Netherlands Reformed Church (1951).

\begin{tabular}{|ll|}
\hline 1. Vergaderingen & General assemblies \\
2. Gemeenten & Congregations \\
3. Verkiezing & Elections \\
4. Apostolaat & Apostolate \\
5. Jeugd en school & Youth and school \\
6. Kerkdienst & Church services \\
7. Opleiding & Education \\
8. Doop & Baptism \\
9. Catechese & Catechism \\
10.Avondmaal & The Lord's Supper \\
11.Opzicht & Supervision \\
12. Huwelijk en gezin & Marriage and family \\
13.Pastoraat & Pastoral care \\
14.Presbyteriaat & Presbyterate \\
15.Diaconaat & Diaconate \\
16.Financien & Finances \\
17. Bezoldiging & Wages \\
18.Toezicht & Supervision \\
19.Bezwaren & Objections \\
20.Oecumene & Ecumenism \\
\hline
\end{tabular}

by the church. In this way, it is connected to the very first article of the theological constitution.

From the perspective of the Dort Church Order of 1619, it was a new development for reformed church orders to contain chapters on the life and work of the church in ecumenical perspective and on finances. Other ordinances have been updated or given new content, as with internal legal procedure, spiritual education and the training of pastors. From the perspective of being a church for the world, this expresses a shift in the ecclesiological nature of the church from the ecclesiology and Church Order of Dort.

\section{The Institutes of Justinian and Early Modern Canon Law}

The previous paragraphs describe developments in church orders before and after Dort, but they do not answer the following question: What is the juridical foundation of the four chapters of the Dort Church Order of 1619? Although reformed church polity broke with the 16th-century Roman Catholic ecclesiological and canonical system, there was less discontinuity than is usually assumed. This is apparent when it comes to the juridical basis of the four chapters of the Dort Church Order of 1619.

Previous to that, in 1234, the Liber Extra or the Decretales of Gregory IX (ca. 1170-1241) became an important element of the Codex Iuris Canonici - the canonical law book of the Roman Catholic church. In the Middle Ages, canon law was mainly developed by the commentaries on the Liber Extra that consisted of about 2000 decrees over five books which were subdivided into 'titles'. However, it was not a complete systematic codification. Early Modern Canonists started to organise a new division of (roman catholic) canon law into four books. The juridical foundation of this division was provided by the four books of the Institutes of the Emperor Justinian I (AD 482-565) (Constitution Society 1995, Hallebeek

BOX 6: The chapters of the church order of the Protestant Church in the Netherlands (2004).

\begin{tabular}{|c|c|}
\hline 1. Het belijden & The confession \\
\hline 2. De gemeenten & Congregations \\
\hline 3. Het ambt en de andere diensten & The office and various ministries \\
\hline 4. De ambtelijke vergaderingen & General assemblies \\
\hline 5. De eredienst & Church services \\
\hline 6. De heilige doop & Holy baptism \\
\hline 7. Het heilig avondmaal & Holy communion \\
\hline $\begin{array}{l}\text { 8. De missionaire, pastorale en the } \\
\text { diaconale arbeid van de gemeente }\end{array}$ & $\begin{array}{l}\text { The Missional, pastoral and diaconate } \\
\text { work of the congregation }\end{array}$ \\
\hline 9. De geestelijke vorming & Spiritual education \\
\hline 10. Het opzicht & Supervision \\
\hline $\begin{array}{l}\text { 11. De vermogensrechtelijke } \\
\text { aangelegenheden }\end{array}$ & Property rights and bussiness affairs \\
\hline $\begin{array}{l}\text { 12. De behandeling van bezwaren } \\
\text { en geschillen }\end{array}$ & $\begin{array}{l}\text { The management of objections and } \\
\text { disputes }\end{array}$ \\
\hline $\begin{array}{l}\text { 13. De opleiding en vorming van } \\
\text { predikanten }\end{array}$ & The education and formation of pastors \\
\hline $\begin{array}{l}\text { 14. Het leven en werken van de kerk in } \\
\text { oecumenisch perspectief }\end{array}$ & $\begin{array}{l}\text { The life and work of the church in } \\
\text { ecumenical perspective }\end{array}$ \\
\hline
\end{tabular}


2011:121, 134; 2014:22-25): the first book on sources of law, personal and family law; the second book on property law and inheritance, focuses on the rights of persons in canon law; the third book on business law and more inheritance law; and the fourth book on offences and procedural law. The Early Modern (Roman Catholic) canonists based their new composition on Justinians Institutes and composition. The Leuven professor, Zeger B. van Espen (1646-1728), composed his Jus Ecclesiasticum Universum (1700) based on Justinians Institutes, albeit he did not use two parts for the law on persons, but just one book or part. Part 1 was on persons (personenrecht); part 2 on the work and its assignment; and part 3 on discipline and procedural law. The Amsterdam professor in Legal History, Jan Hallebeek, agrees that also the Early Modern Dort Church Order of 1619 was composed in the way of Justinians Institutes. Chapters 1 (offices) and 2 (The General Assemblies) are related to Justinians personal and family law; chapter 3 (Doctrine, Sacraments and other Ceremonies) to Justinians business law; and chapter 4 (Admonition and Discipline) to his offences and procedural law (Hallebeek 2017).

\section{Conclusion}

A church order, also a reformed church order, is theological in content and (church) juridical in its framework. However, from the perspective of a reformed church order, this framework reveals also something about the theological expression of the nature of the reformed church. It is not only a juridical framework, but also theological. The chapters or paragraphs that compose together the church order also expresses the doctrina and disciplina of the reformed church.

From the reformed-confessional perspective, it seems clear that the content of the Dort Church Order of 1619 is largely based on the three notae ecclesiae of the Belgic Confession, and so upon doctrine and discipline. This does not necessarily explain why this church order has four chapters. Although the Dort Church Order of 1619 indeed reflects the reformed-confessional doctrine and discipline according to the Belgic Confession, its division into four chapters also has a juridical dimension. It was based on the system of Justinian's Institutes and the work of Early Modern Canonists. Although the canonical law system was detested and disapproved by those who espoused the reformed system of governance, they implemented the methodological work of the Early Modern Canonists based on the Justinian's Institutes. Expertise in reformed church polity did not start anew with the Dort Church Order of 1619, but it was based on its predecessors. There was some, even if only a little, continuity between the Roman Catholic system of composing canonical law books and the reformed churches composing their orders. However, this system can neither be found in the Genevan Articles of 1537, nor in the Ordonnances of 1541 and 1561. Neither is it in the French Discipline Ecclésiastique of 1559. They have a longer set of chapters in their (draft) church orders.
The Dort division has been applied in some overseas territories - more specifically in the East-Indies. The Batavian Church Order of 1643 implemented the four chapters of the Dort Church Order of 1619, revised it a little and added a long appendix, mainly concerning the assignment of comforters of the sick, and schoolmasters. New contexts require revision of church order and sometimes even new orders. That is illustrated by the situation in the Netherlands in 1816.

The division of the four chapters in the Dort Church Order of 1619 was ignored in the 'church order' imposed by King Willem I - the General Regulations of 1816 (het Algemeen Reglement van 1816). A new set of subthemes or chapters, which demonstrates the administrative nature of the Netherlands Reformed Church (Nederlandse Hervormde Kerk) and also the centralised system of church governance, was implemented. After 135 years, these General Regulations of 1816 were replaced by a more theological church order: de Hervormde Kerkorde of 1951. That church order as well as its successor - the church order of the Protestant Church in the Netherlands - has two main parts in line with the law of the constitution. It has a theological constitution such as the state constitution and a set of ordinances, comparable to the state organic laws. These laws, just like the ecclesiastical ordinances, are easier to change than the constitution. New constitutional developments were implemented in church law. This demonstrates that church polity is a multidisciplinary field with canonistst, experts in reformed church polity and jurists.

However, the division of the four chapters in the Dort Church Order of 1619 is still valid in reformed church orders - mostly (revisions of) the Dort Church Order of 1619 in, among others, the Netherlands, North America, South Africa, Asia, Australia and New-Zealand. The composition of reformed church orders demonstrate not only theological craftmanship, but also a juridical one, and not only a juridical one, but also theological craftmanship. They need each other for the benefit of reformed church polity and church order, to glorify God and to serve the church of Christ.

\section{Acknowledgements}

This article is an elaboration of the lecture I presented on 20 October 2017 at the Faculty of Theology, North-West University Potchefstroom, South Africa. I thank the staff and students for their feedback. Also, I would like to thank Jan Hallebeek, professor in Legal Theory and Legal History at the Faculty of Law, Vrije Universiteit Amsterdam for his assistance. Also, I thank Dr Allan Janssen and David Harte for their help with my English grammar.

\section{Competing interests}

The author declares that he has no financial or personal relationships which may have inappropriately influenced him in writing this article. 


\section{References}

'Articles concernant l'organisation de l'église et du culte a Genève, proposés au conseil par les ministers, le 16. Janvier 1537', 1871, in W. Baum, E. Cunitz \& E. Reuss (eds.), Calvini Opera [CO] 10/1, pp. 5-14, A. Schwetschke et filium (M. Bruhn), Brunsvigae.

Balke, W. \& Oostenbrink-Evers, H. (eds.), 1993, De Commissie voor de Kerkorde (1945-1950): Bouwplan, agendastukken en notulen van de vergaderingen ter voorbereiding van de nieuwe kerkorde (1951) van de Nederlandse Hervormde Kerk, Boekencentrum, Zoetermeer.

Balke, W. \& Oostenbrink-Evers, H. (eds.), 1995, De Commissie voor de Werkorde (1942-1944), Boekencentrum, Zoetermeer.

Bohatec, J., 1968, Calvins Lehre von Staat und Kirche: Mit besonderer Berücksichtigung des Organismusgedankens, 2nd edn., Scientia, Aalen.

Bos, F.L., 1950, De orde der kerk, toegelicht met kerkelijke besluiten uit vier eeuwen, Guido de Bres, 's-Gravenhage.

Bouwman, H., 1928-1934, Gereformeerd kerkrecht: Het recht der kerken in de practijk, vol. 2, Kok, Kampen.

Brink, W.L. \& De Ridder, R.R., 1980, Manual of Christian Reformed Church Government Board of Publications of the Christian Reformed Church, Kalamazoo/Grand Rapids, MI.

Church Order of the Free Reformed Churches of Australia, 2015, 'Church Order of the Free Reformed Churches of Australia as adopted by Synod 2003 and including subsequent amendments by FRCA synods up to 2015', viewed 09 May 2018, from http://synod.frca.org.au/churchorder/ChurchOrder_of_the_FRCA (2015).pdf

CO see Articles concernant l'organisation de l'église et du culte a Genève, proposés au conseil par les ministers, le 16. Janvier 1537

Coertzen, P., 1992, 'Enkele gedagtes oor 'n kerkorde', HTS Teologiese Studies/ Theological Studies 48(3\&4), 717-729.

Coertzen, P., 1998, Church and order: A reformed perspective, Peeters, Leuven. (Canon Law Monography Series 1), Dudley, MA.

Coertzen, P., 2004, 'Decently and in order': A Theological Reflection on the Order for and the Order in, the Church, Peeters, leuven. (Canon Law Monograph Series, 4), Dudley, MA.

Constitution Society 1995, Institutiones of Justinian, viewed 20 November 2017, from $\mathrm{http}: / / w w w . c o n s t i t u t i o n . o r g / s p s / s p s 02$ j1-1.htm

De Wet, C.J.H., 1921, Die kollegiale kerkreg, H.A. van Bottenburg, Amsterdam.

Deddens, D., 1988, 'De Nederlandse Gereformeerde Kerken in de Periode 1560-1816', in W. van 't Spijker \& L.C. van Drimmelen (eds.), Inleiding tot de studie van het kerkrecht, pp. 110-120, Kok, Kampen.

Du Plessis, J.A., 1924, Die Gereformeerde Kerken Kerkregering: Gehandhaaf - teen Prof. Dr. J. du Plessis van Stellenbosch, Nasionale Pers, Bloemfontein.

Du Plooy, A.L.R., 2012, 'Die hermeneutiek van gereformeerd kerkreg', In die Skriflig 46(1), Art. \#36, 8 pages. http://dx.doi.org/10.4102/ids.v46i1.36

Duursema, G.J., 2017a, Communio Sanctorum: Gereformeerd kerkreg versus kerklike geskeidenheid, 'n Biografiese bibliografie van WD Jonker 1955-1968, Willie Jonker Digitale Argief, Stellenbosch.

Duursema, G.J. (ed.), 2017b, Die regering van Christus in sy Kerk: Geskiedenis van die ontwikkeling van die Gereformeerde kerkreg, Willie Jonker Digitale Argief, Stellenbosch.

Eybers, J.H., 1934, Die kerkinrichting van de Nederduits Gereformeerde Kerke in SuidAfrika: Getoets aan die beginsels van gereformeerde kerkreg, Schweizer Reneke, Pretoria.

Hallebeek, J., 2011, Canoniek recht in ecclesiologische context: Een inleiding tot het kerkelijk recht van de Oud-Katholieke Kerk van Nederland, Merwedeboek, Amersfoort/Sliedrecht. (Publicatieserie Stichting Oud-Katholiek Seminarie, 49).

Hallebeek, J., 2014, Lijf ende goedt: De juridische bescherming van de menselijke persoon en diens vermogen. Een schets van de westerse rechtsgeschiedenis, VU University Press, Amsterdam.

Hallebeek, J., 2017, e-mail, 17-19 October, j.hallebeek@vu.nl.

Hovius, J., 1962, 'Het verband tussen onze Belijdenis en onze Kerkorde: Enkele opmerkingen', Rede uitgesproken bij de overdracht van het Rectoraat aan de Theologische Hogeschool der Chr. Gereformeerde Kerken te Apeldoorn op 9 oktober 1962, B. Weissenbach \& Zoon, Sneek.

Jansen, J., 1952, Korte verklaring van de kerkorde der Gereformeerde Kerken, vol. 3, Kok, Kampen.

Janssen, A.J., 2000, Constitutional theology: Notes on the Book of Church Order of the Reformed Church in America, Wm. B. Eerdmans, Grand Rapids, MI. (Historical Series of the Reformed Churches, 33).

Kerkorde voor de Bataviasche gemeente, 1886, 'Kerkorde voor de Bataviasche gemeente afgekondigd 7 december 1643', in J.A. van der Chys (ed.), Nederlandsch-Indisch plakaatboek, 1602-1811, Tweede deel: 1642-1677, pp. 31-57, Nijhoff, Batavia.

Kleynhans, E.P.J., 1982, Gereformeerde kerkreg: Inleiding, NG Kerkboekhandel Transvaal, Pretoria.
Koffeman, L.J., 2014, In order to serve: An ecumenical introduction to Church Polity, Wien/Zürich/Berlin/Münster, LIT-Verlag. (Church Polity and Ecumenism: Global Perspectives, 1).

Kruger, L.S., du Plessis, H.L.M., Spoelstra, B \& Spoelstra, T.T. (eds.), 1966, Handleiding by die kerkorde van die Gereformeerde Kerk in Suid-Afrika, Pro Rege Pers Beperk, Potchefstroom.

Nauta, D., 1971, Verklaring van de kerkorde van de gereformeerde kerken in Nederland, Kok, Kampen.

Nauta, D. \& Van Dooren, J.P. (eds.), 1978, De nationale synode van Dordrecht 1578: Gereformeerden uit de Noordelijke en de Zuidelijke Nederlanden bijeen, Buijten \& Schipperheijn en Ton Bolland in samenwerking met het Kerkhistorisch Gezelschap, Amsterdam.

Oostenbrink-Evers, H., 2000, Beginselen en achtergrond van de kerkorde van 1951 van de Nederlandse Hervormde Kerk: Een kerkrechtelijk onderzoek naar de structuu van de Nederlandse Hervormde Kerk, zoals die werd ontworpen door de Commissie voor beginselen van Kerkorde (1942-1944) en de Commissie voor de Kerkorde (1945-1947), Boekencentrum, Zoetermeer.

Opitz, P., 2006, 'Ordonnances Ecclésiastiques, genf 1541/1561', in H. Faulenbach \& E. Busch (eds.), Reformierte Bekenntnisschriften, vol. 1/2 1535-1549, Neukirchener Verlag, Neukirchen-Vluyn, pp. 229-278.

Pont, A.D., 1981, Die historiese agtergronde van ons kerklike reg, Haum, Pretoria \& Kaapstad.

Schutte, G.J. (ed.), 2002, Het Indisch Sion: De Gereformeerde kerk onder de Verenigde Oost-Indische Compagnie, Verloren, Hilversum.

Sizoo, A., 1956, Johannes Calvijn Institutie of Onderwijzing in de christelijke godsdienst uit het Latijn vertaald, vol. 3, bevattende boek IV, 3rd edn., Delft, W.D. Meinema.

Smit, C.J., 1984, God se orde vir sy kerk: 'n Beskouing oor kerkorde, NG Kerkboekhandel, Transvaal Pretoria.

Smit, C.J. (red.), 1986, In gehoorsaamheid: Opgedra aan prof. dr. G.P.L. van der Linde, Potchefstroom Teologiese Publikasies, Potchefstroom.

Smit, C.J., 1987, 'Kerkreg en kerkorde in diens van die kerkregering: Oorsig oor in beskouing', In die Skriflig 21(82), 17-27.

Spoelstra, B., 1981, 'Calvynse Kerkreg en invloed op kerke in Suid-Afrika', In die Skriflig 15(59), 4-23.

Spoelstra, B., 1989, Gereformeerde kerkreg en kerkregering: 'n Handboek by die Kerkorde, Die Hammanskraalse Teologiese Skool van die Gereformeerde Kerke in Suid-Afrika, Hammanskraal.

Strauss, P.J., 2003, 'Ekumeniese kerkreg: Die aangewese weg?', In die Skriflig 47(1), Art. \#73, 7 pages. http://dx.doi.org/10.4102/ids.v47i1.73

Strauss, P.J., 2017, "n Kerkorde in gereformeerde kerke toegepas op die Nederduitse Gereformeerde Kerkorde van 2013', In die Skriflig 51(1), a2215. https://doi. org/10.4102/ids.v51i1.2215

Van Boetzelaer Van Dubbeldam, C.W.T.B., 1906, De Gereformeerde Kerken in Nederland en de Zending in Oost-Indië: In de Dagen der Oost-Indische Compagnie, P. den Boer, Utrecht.

Van Dellen, I. \& Monsma, M., 1941, The Church Order Commentary: Being a Brief Explanation of the Church Order of the Christian Reformed Church, Zondervan Publishing House, Grand Rapids MI.

Van Dellen, I. \& Monsma, M., 1970, The Revised Church Order Commentary: An Explanation of the Church Order of the Christian Reformed Church, 4th edn., Zondervan Publishing House, Grand Rapids, MI.

Van der Linde, G.P.L., 1965, Die grondbeginsels van die Presbiteriale kerkregeringstelsel, Pro Rege-Pers Beperk, Potchefstroom.

Van der Linde, G.P.L. 1983, Die kerkorde:'n Verklaring van die gereformeerde kerkorde, T.G. van Wyk Drukkers, Pretoria.

Van Dooren, J.P. (ed.), 1981, De nationale synode te Middelburg in 1581: Calvinisme in opbouw in de Noordelijke en Zuidelijke Nederlanden, Koninklijk Zeeuwsch Genootschap, Middelburg.

Van Espen, Z.B., 1700, Jus ecclesiasticum universum hodiernæ disciplinæ præsertim Belgii, Galliæ et vicinarum provinciarum accommodatum .... 2 tom., sumptibus Belgii, Galliæ et vicinarum provinciarum accommodatum ..., 2 tom ..
Guilielmi Stryckwant ... et Bruxellis, Francisci T'Serstevens ..., Lovanii.

Van Rongen, G. \& Deddens, K., 1986, Decently and in good order: The Church Order of the Canadian and American Reformed Churches, Premier Publishing, Winnipeg.

Van 't Spijker, W., 1992, 'Rechtvaardiging en recht in de kerk: Over de theologische achtergronden van het gereformeerde kerkrecht', Hervormde Teologiese Studies 48(3 \& 4), 995-1011.

Van 't Spijker, W., De Bruin, C.C., Florijn, H., Moerkerken, A. \& Natzijl, H. (eds.), 1994, De Synode van Dordrecht in 1618 en 1619, 2nd. edn., Den Hertog, Houten.

Van Wyk, B., 2017, 'Die verband tussen ekklesiologie en kerkreg: 'n Hervormde perspektief', HTS Teologiese Studies/Theological Studies 73(1), a4608. https://doi. org/10.4102/hts.v73i1.4608

Voetius, G., 1663-1676, Politica Ecclesiastica, vol. 4, ex officinâ Joannis à Waesberge, Amstelodami.

Wagenaar, H.M.J., 1993, 'Inleiding', in W. Balke \& H. Oostenbrink-Evers (eds.), De Commissie voor de Kerkorde, pp. XXXVII-LVIII, Boekencentrum, Zoetermeer. 